UNIVERSITY OF CHITRAL JOURNAL OF LINGUISTICS AND LITERATURE

VOL. 4 | ISSUE I | JAN - JUNE | 2020

ISSN (E): 2663-1512, ISSN (P): 2617-3611

\title{
Analysis of Pakistan's National Curriculum for English: A Learner-Centered Ideology
} Perspective

\author{
Kamran Akhtar Siddiqui \\ Lecturer in English, Sukkur IBA University, Sukkur, Pakistan \\ kamran.akhtar@iba-suk.edu.pk
}

Abstract

Curriculum is said to be the blueprint that lays down not only educational goals but also the ways to attain those goals. The blueprint is highly ideologically influenced and this is reflected in the goals set by the developers of the curriculum. The National Curriculum for English published in Pakistan in 2006 is considered an updated document with contribution from all key stakeholders; however, the literature on curriculum studies lacks any study that has been carried out to understand its ideological nature. Hence, the purpose of this study is to analyze the National English Curriculum from a learner-centered ideological perspective. Use qualitative methods to close reading of the document was done to carefully find useful excerpts of the text and label according to the purpose of the study. The results show that the curriculum follows the learner-centered ideology in terms of subject matter, content knowledge, teaching process and the role of students and teachers. However, in terms of assessment, it follows a traditional approach. The study concluded that the assessment part of the curriculum needs to follow a more formative and innovative assessment approach to make the document more learnercentric in nature. Moreover, the study puts forward a few recommendations with respect to the training of teachers, the provision of guidance strategies for teachers, and the allocation of more proportions for formative assessments.

Keywords: Curriculum, Curriculum Ideology, Learner-centered Ideology.

\section{Introduction}

Countries attain their long-term goals in the field of education and through the field of education using curriculum as a road map. Each curriculum is based on certain beliefs and concepts that form the ideology of curriculum. The four main curriculum ideologies that Schiro (2008) introduced are scholar academic ideology, social efficiency ideology, learner-centered ideology and social reconstruction ideology.

Ministry of Education, Pakistan has also developed a curriculum for English much like other subjects taught and studied in Pakistan. English is the most important curriculum of all because English is not only the lingua-franca of the world but also the official language of Pakistan (Shamim, 2008). Although the revised English curriculum published in 2006 is claimed to be an up-to-date document, no study confirms its learner-centred nature. Therefore, the purpose of this study is to analyze the National Curriculum for English (Grade I-XII) from a learner-centered ideological perspective.

This study debates that the curriculum under study is developed from the perspective of learnercentered ideology, because it focuses on individual skills development, making meaning through experience, application of cooperative activities, the role of teachers as facilitators and the role of 
UNIVERSITY OF CHITRAL JOURNAL OF LINGUISTICS AND LITERATURE

VOL. 4 | ISSUE I | JAN - JUNE | 2020

ISSN (E): 2663-1512, ISSN (P): 2617-3611

students as active learners. However, in terms of assessment, it does not meet this ideological point of view.

Purpose of the Study

This study aims at analyzing Pakistan's National Curriculum for English (Grade I-XII) from the lens of learner centered ideology.

\section{Significance of the Study}

This study is important for the entire research community, especially for researchers who examine the curriculum from an ideological perspective. The study is also important for curriculum developers and researchers in Pakistan as these findings may guide them in tailoring the English curriculum or that of any other subject according to learner-centered ideology.

\section{Literature Review}

\section{Curriculum and Curriculum Ideology}

Narrowly speaking, curriculum is deemed as a catalogue of subjects and content to be taught in an academic environment. More broadly, the curriculum is the sum of an individual's learning experience not only at school but also in society (Ozar, 1994). Moreover, several educational goals and objectives are achieved through curriculum ( $\mathrm{Su}, 2012)$. Each country designs curricula according to its needs (social, political, religious and other). Therefore, the curriculum is a set of norms on which society depends for survival and continuation (Egan, 1978).

When these norms and beliefs become part of the curriculum, the curriculum ideology develops. Curriculum ideology is described as "personal beliefs about what educational institutions should teach, for what purpose and for what reason" (Slethaug, 2007). Moreover, Schiro (2008) terms "objectives of education as curriculum ideologies".

\section{Curriculum Ideologies}

Each curriculum is influenced by certain ideologies. Curriculum ideology is a special belief in the content of educational institutions: the purpose, methods and ways of teaching content and the reasons why the content of teaching is useful (Slethaug, 2007). Ideology about curriculum "refers to the general philosophy and educational field that support curriculum descriptive theory" (Farahani \& Maleki, 2014). Taking a leaf from the book "Topic Specialized Curricula" by TalebZadeh Nobarin, M. \& Fathi Vajargah, K. (2002), the ideology of the curriculum can be seen as a set of principles for determining the decision-making needs in the field of education.

Schiro (2008) proposed four curriculum ideologies and developed a questionnaire through which one could judge the curriculum ideologies (Marulcu \& Akbiyik, 2014). These curriculum ideologies can be divided into four types: Scholar Academic Ideology, Social Efficiency Ideology, Social Reconstruction Ideology and Learner Centered Ideology. According to Mnguni (2013), Schiro also stated that every curriculum ideology possesses particular features that relate to the aim of the subject, content knowledge, and the instructional process, the role of the students, the role of teachers, and assessment.

\section{Scholar Academic Ideology}

This ideology points out that over the years, people have accumulated a wealth of knowledge and divided it into different disciplines which novice learners must learn as it is. The ultimate goal of 
UNIVERSITY OF CHITRAL JOURNAL OF LINGUISTICS AND LITERATURE

VOL. 4 | ISSUE I | JAN - JUNE | 2020

ISSN (E): 2663-1512, ISSN (P): 2617-3611

this idea is to extend the accumulated knowledge to new learners. This is designed to foster a new culture for individuals; therefore, it is done on a cultural and personal level (Marulcu \& Akbiyik, 2014).

\section{Social Efficiency Ideology}

Proponents of this curriculum ideology argue that the curriculum must be used as a tool for creating such members of society who contribute to society in many different ways and thus can meet the needs of society (Marulcu \& Akbiyik, 2014). This is- as they call it- scientific instrumentalism meaning use of curriculum as a scientific instrument. Schiro (2008) states that the "curriculum developers in the field of social efficiency ideology "have supreme faith in the ability of education, through the medium of curriculum, to educate students to understand the nature of their society in such a way that they will develop a vision of a better society, and then act so as to bring that vision into existence".

\section{Social Reconstruction Ideology}

This ideology is curriculum from a social point of view. It stated that society was weak and had many "problems of our society and the injustices done to its members, such as those originating from racial, gender-based, social, and economic inequalities"(Farahani \& Maleki, 2014), and that there was an urgent need to rebuild it. Teachers and students are active drivers of this change, as structural change begins with the remodeling of the classroom environment, which reshapes the tenderness of the children. This remodeling can help students envision society in a different, better way. Therefore they can create a world around them which is fair and equitable (Schiro, 2008).

\section{Learner Centered Ideology}

The idea is to provide a more enjoyable learning environment to children, in which teachers create meaningful experiences and students learn socially and interactively. Schiro points out that children have innate abilities and the potential to learn new things (Farahani \& Maleki, 2014).

Since Pakistan's national English curriculum is being analysed from a learner-centered ideological perspective, it will be discussed in detail in the following paragraphs.

Research shows that learner-centered ideology "is a phenomenon that puts learners at the center." The learner-centered ideology emphasizes that education must help students develop skills and abilities. According to proponents of this ideology, the main objective of the theme is to realize the potential of children (Taylor, Bogdan, \& DeVault, 2015). According to Ahmed (2010), performance of students is best when they do what they like the most.

The learner-centered ideological advocates argue that knowledge is the sum of the meanings that children create through experience and interaction with peers, textbooks and mentors. Therefore, the main task of educators is to carefully create that environment to encourage children to grow up during the meaning construction process. For them, the locus of whole teaching process is the child, and his growth should be the ultimate goal of learning. They think children are an active part of the class and the role of teacher is limited to being a facilitator. Assessment is more formational and subjective. This means that a child's continual progress can be tracked and tested in specific areas that he already has mastered. This means that the goal of education can be seen 
UNIVERSITY OF CHITRAL JOURNAL OF LINGUISTICS AND LITERATURE

VOL. 4 | ISSUE I | JAN - JUNE | 2020

ISSN (E): 2663-1512, ISSN (P): 2617-3611

as a scaffolding that helps people develop their natural abilities that, later on, can be applied in future actions.

\section{Pakistan's National Curriculum for English}

Following considerable efforts and consultations with all stakeholders, the main policy document, the National Curriculum for English was launched in 2006 (Ministry of Education, 2006). The new curriculum was introduced because the previous English curriculum was criticized for being outdated and teacher-centered. This document provides comprehensive guidance for English teaching throughout Pakistan from grades 1 to 12. It provides for the integration of all language components and identifies strategies for developing all areas and skills of English. From the perspective of curriculum developers, the updated English curriculum not only outlines knowledge acquisition, but also emphasizes language skills to ensure the overall development of learners. As a result, the curriculum focuses primarily on developing learners' communication skills and "focuses on teaching language instead of teaching about the language"(Jadoon, Chishti, Afzaal, \& Afzal, 2020). This clearly implies that the National English Curriculum was drafted under the influence of a learner-centered ideology.

Although studies have been conducted in the past to examine the links between the abovementioned curriculum and the classroom syllabus (Jabreel Asghar, 2014) and to analyze the document from Cognitive Strategy Instruction perspective (Jamil Asghar \& Butt, 2018), the literature lacks any empirical research to prove that the National English Curriculum is consistent with a learner-centered ideology.

Therefore, this paper contributes to the literature by analyzing the National English Curriculum (Levels I to XII) from a learner-centered ideological perspective, and reports its theoretical nature.

\section{Research Question}

To what extent Pakistan's National Curriculum for English aligns with learner-centered Ideology?

\section{Methodology}

Qualitative methods were used to analyze Pakistan's National Curriculum for English. Qualitative methods help to better interpret ideas because they allow researchers to interpret them without any restrictions. (Taylor et al., 2015). The text was closely read and was evaluated from a learnercentered ideological perspective, and the interpretations were made.

In order to analyze the curriculum from the said perspective, curriculum analysis inventory by Schiro (2008) was employed which comprised six open-ended questions (Table 1) and was used as analysis guide.

Table 1 A tool used for studying components of the National Curriculum for English (Adapted from Schiro, 2008).

\begin{tabular}{|l|l|l|}
\hline $\begin{array}{l}\text { Purpose of analysis } \\
\text { of English curriculum }\end{array}$ & Data & $\begin{array}{l}\text { Open-ended questions for } \\
\text { analysis of curriculum }\end{array}$ \\
\hline
\end{tabular}


UNIVERSITY OF CHITRAL JOURNAL OF LINGUISTICS AND LITERATURE

VOL. 4 | ISSUE I | JAN - JUNE | 2020

ISSN (E): 2663-1512, ISSN (P): 2617-3611

\begin{tabular}{|l|l|l|}
\hline \hline $\begin{array}{l}\text { To analyze its contents from } \\
\text { learner centered ideology }\end{array}$ & $\begin{array}{l}\text { National Curriculum for } \\
\text { English language }\end{array}$ & $\begin{array}{l}\text { a) What is the aim of the } \\
\text { curriculum? } \\
\text { b) What kind of knowledge is } \\
\text { prescribed in the curriculum? } \\
\text { c) How is learning supposed to } \\
\text { take place? } \\
\text { d) What is the nature and the } \\
\text { role of students in the learning } \\
\text { process? } \\
\text { e) What is the role of teachers } \\
\text { during instruction? } \\
\text { f) What is the purpose of } \\
\text { assessment? }\end{array}$ \\
\end{tabular}

\section{Findings and Discussion}

The results show that Pakistan's National Curriculum for English largely reflects the learnercentered thinking. The author has tried to identify themes as well as sub themes of ideology.

\section{Aim of the Subject}

According to the learner-centered ideology, the aim of the subject should be to help students reach their full potential so that they can create personal meanings and respond creatively to life experiences. The curriculum analyzed is also designed with an aim to equip learners with academic and practical skills so that they can complete their studies and develop their careers after graduation from school (Ministry of Education, 2006). In addition, learner-centered ideology suggests that children use their own experiences to create meaning and form their own knowledge. This means that students will be involved in real-life situations so that they can combine learning with reallife life. The curriculum under study also focuses on enabling students to experience different reallife situations and use language in context, rather than learning the language themselves (Ministry of Education, 2006).

\section{Instructional Process}

The learning-centered ideology keeps learners at the center of learning in the instructional process, thus, it focuses on the growth of learners. The National Curriculum for English also seems to follow this ideological teaching process. The curriculum points out that the structure and integration of the learning process lies in the student's ability to achieve competencies "through a spiral progression" and that the main focus should be on mastering the language rather than the content. Activities must also be designed to enable students to access information and ideas through listening and reading, and to communicate through spoken language and writing, so all four skills must be integrated. It also proposes strategies such as discussions, role-playing, presentations and projects, cooperative learning, and more to keep learners active and central point of the process.

\section{Role of Students and Teachers}

According to the learner-centered ideology, the learner is active in the learning process, and the teacher considers them as they are. The implied meaning of the ideology here is that there are 
UNIVERSITY OF CHITRAL JOURNAL OF LINGUISTICS AND LITERATURE

VOL. 4 | ISSUE I | JAN - JUNE | 2020

ISSN (E): 2663-1512, ISSN (P): 2617-3611

differences in learning style, nature, background, etc. of learners. The role of a teacher is described as a role of a facilitator that stimulates student diversity and creates an environment for children to interact. In short, students should be active and teachers should supervise classroom activities.

Pakistan's National Curriculum for English treats learners as poor and therefore emphasizes that students should be provided with "formal opportunities to learn the language" which are outlined in this well-thought-out and organized curriculum (Ministry of Education, 2006). It also discusses the design and use of activities in the classroom that not only allow students to interact with each other, but also correct each other's mistakes through peer correction (Ministry of Education, 2006). It also noted that such an environment should be provided "to suit the different interests, abilities and learning styles of students" (Ministry of Education, 2006, P158). This suggests that the course discusses and highlights one of the four Cs of the 21 st century.

\section{Assessment}

Assessment as per learner centered ideology is done to diagnose the students' abilities to facilitate their growth. Tools like Portfolio, Teachers notes, Teachers 'diaries, Developmental checklist, Learning logs and generals are used. This implies that assessment is formative and subjective, as each learner learns at his or her own pace and needs. The assessment part in the curriculum, on the other hand, is dominated by summary evaluation tools, such as selected constructs to answer questions, essay questions, performance tasks (e.g. projects), etc. (Ministry of Education, 2006).

The results of the analysis show that Pakistan's National Curriculum for English tends to be a learner-centered in its ideological nature as discussed by (Schiro, 2008). However, it lacks the quality of a developed learner-centered curriculum. First, it does not allow learners much space to define their learning goals, which in the long run will not develop their personal abilities. Students must have some freedom to choose their learning goals or design courses under the guidance of their teachers in order to make learning more inclusive and engaging. Second, stakeholders should use this curriculum as a reference (Ministry of Education, 2006); this means that teachers can use this document as a guide for teaching purposes. Conversely, the sad thing about the story is that they are not sufficiently trained to properly intervene based on the curriculum to alter student's experience. As Jadoon et al. (2020) report that teachers lack adequate training to cope with the revised curriculum and therefore can only rely on their previous experience. Based on these findings, this study provides some recommendations.

\section{Recommendations}

Teachers should receive pre- and on-the-job training so that they are familiar with their roles and how to play them. In this regard, certain teaching strategies must be shared with teachers, who are unable to explore them on their own for a variety of reasons, particularly the lack of ICT skills. In view of the inefficiency of teachers' curriculum understanding, curriculum development under teacher guidance and learner autonomy become distant goals. Third, the final results should be based on a formative assessment and should provide descriptive feedback so that learners can trace their progress.

\section{Conclusion}

In summary, it is noted that the Pakistan's National Curriculum for English focuses on learners' skills development, integrating their learning into the environment through cooperative activities, 
UNIVERSITY OF CHITRAL JOURNAL OF LINGUISTICS AND LITERATURE

VOL. 4 | ISSUE I | JAN - JUNE | 2020

ISSN (E): 2663-1512, ISSN (P): 2617-3611

and that the role of teachers has changed from sages on stage to facilitators and roles of learners from passive learners in the classroom to active learners. However, traditional assessment tools, such as constructed answer questions, paper questions, and other methods used for final assessment reflect the learner-centered ideology in the document that needs to be improved. Therefore, rather than making drastic changes in the current National Curriculum for English, some changes should be made in the field of assessment to bring classroom learning into keeping with assessment practices.

\section{References}

Ahmed, A. H. (2010). Students' problems with cohesion and coherence in EFL essay writing in Egypt: Different perspectives. Literacy Information and Computer Education Journal (LICEJ), 1(4), 211-221.

Asghar, J. (2014). Review of reading goals in the national curriculum of English language (grades 11-12) in Pakistan. Academic Research International, 5(3), 292.

Asghar, J., \& Butt, M. I. (2018). A Critique of National Curriculum for English Language in Pakistan: Proposing Cognitive Strategy Instruction for ELT. Kashmir Journal of Language Research, 21(1).

Egan, K. (1978). What is curriculum? Curriculum Inquiry, 8(1), 65-72.

Farahani, M. F., \& Maleki, M. (2014). A survey on tendency toward curriculum ideologies among academic board members in educational sciences faculties-Tehran 2010-11. ProcediaSocial and Behavioral Sciences, 116, 2392-2396.

Jadoon, A. U. R., Chishti, M. I., Afzaal, M., \& Afzal, T. (2020). Challenges Faced by Newly Inducted Teachers Implementing Revised English Curriculum in Pakistan. English Language Teaching, 13(7), 52-66.

Marulcu, I., \& Akbiyik, C. (2014). Curriculum Ideologies: Re-exploring Prospective Teachers' Perspectives. International Journal of Humanities and Social Science, 4(5), 1.

Ministry of Education, Government of Pakistan. (2006). National Curriculum for English

Language Grades I - XII. Retrieved from http://bisep.com.pk/downloads/curriculum/Grades-I-

XII/pk_al_eng_2006_eng.pdf

Mnguni, L. (2013). The curriculum ideology of the South African secondary school Biology. South African Journal of Education, 33(2).

Ozar, L. A. (1994). Creating a Curriculum That Works: A Guide to Outcomes-Centered Curriculum Decision-Making: ERIC.

Schiro, M. S. (2008). Schiro, Michael Stephen, Curriculum Theory: Conflicting Visions and Enduring Concerns. Thousand Oaks, CA: Sage Publications, 2008.

Shamim, F. (2008). Trends, issues and challenges in English language education in Pakistan. Asia Pacific Journal of Education, 28(3), 235-249.

Slethaug, G. E. (2007). Teaching abroad: International education and the cross-cultural classroom (Vol. 1): Hong Kong University Press.

Su, S.-W. (2012). The Various Concepts of Curriculum and the Factors Involved in Curriculamaking. Journal of language teaching \& research, 3(1).

Taylor, S. J., Bogdan, R., \& DeVault, M. (2015). Introduction to qualitative research methods: A guidebook and resource: John Wiley \& Sons. 
UNIVERSITY OF CHITRAL JOURNAL OF LINGUISTICS AND LITERATURE

VOL. 4 | ISSUE I JAN - JUNE | 2020

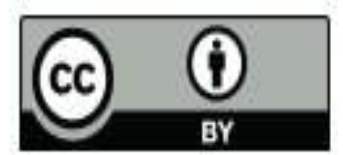

@ 2017 by the author. Licensee University of Chitral, Journal of Linguistics \& Literature, Pakistan. This article is an open access article distributed under the terms and conditions of the Creative Commons Attribution (CC BY) (http://creativecommons.org/licenses/by/4.0/). 